\section{FACTOR ANALYSIS OF THE MINNESOTA LEISURE TIME ACTIVITIES QUESTIONNAIRE - BRAZILIAN PORTUGUESE}

\author{
ANÁLISE FATORIAL DO MINNESOTA LEISURE TIME ACTIVITIES QUESTIONNAIRE - PORTUGUÊS-BRASIL
}

ANÁLISIS FACTORIAL DEL MINNESOTA LEISURE TIMEACTIVITIES QUESTIONNAIRE - PORTUGUÉS-BRASIL

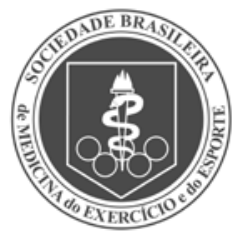

Original Article ARtigo Original Artículo Original
Lygia Paccini Lustosa'

(Physiotherapist)

Silvia Lanziotti Azevedo da Silva² (Physiotherapist)

Taís Almeida Marra ${ }^{3}$ (Physiotherapist)

João Marcos Domingues Dias ${ }^{4}$ (Physiotherapist)

Leani Souza Máximo Pereira' (Physiotherapist)

Rosangela Correa Dias ${ }^{4}$ (Physiotherapist)

\section{Universidade Federal de Minas Gerais, Department of Physiotherapy, Programa de Pós-graduação em Ciências da Reabilitação, Belo Horizonte, MG, Brazil. \\ 2. Universidade Federal de Alfenas (UNIFAL), MG, Brazil. \\ 3. Faculdade Pitágoras, Belo Horizonte, MG, Brazil. \\ 4. Universidade Federal de Minas Gerais, Programa de Pós-graduação em Ciências da Reabilitação, Belo Horizonte, MG, Brazil.}

\section{Correspondence:}

Escola de Educação Física, Fisioterapia e Terapia Ocupacional. Campus Pampulha.

Av. Antonio Carlos 6627, Belo Horizonte, MG, Brazil. 31270-901.

lygia.paccini@gmail.com

\begin{abstract}
Introduction: Accurate measures of physical activity to establish dose-response relationship in health outcomes are still controversial. Scales that estimate caloric expenditure are proposed with a view to categorizing the phenomenon globally. Objective: To carry out a factor analysis of the structure of the Minnesota Leisure Time Activities Questionnaire - Brazilian Portuguese, and propose a new adapted version for the Brazilian elderly community. Methods: Participants were elderly female members of the community, without any distinction in terms of ethnic group and/or social class, who frequented extension projects of two higher education institutions. Those with cognitive impairments; dependence on walking aids; musculoskeletal pain in the last two weeks and neurological diseases were excluded from the study. All participants answered the questionnaire with sociodemographic and clinical data and the Minnesota Leisure Time Activities Questionnaire - Brazilian Portuguese version. We determined whether each activity had been undertaken by the participants and the average number of times it was performed over the last two weeks, considering average time, in minutes, on each occasion. Each activity was considered a single item and energy expenditure was calculated according to the authors' instructions. We used factor analysis with Varimax orthogonal rotation, excluding items whose variance was equal to zero. Correlation between items was determined using the Pearson correlation matrix. Internal consistency between items, before and after the factor analysis, was verified using Cronbach's a coefficient. 5\% significance level. Results: Participants were 220 women (70.8 \pm 5.9 years). The factor analysis resulted in 10 components, which explained, in total, $61.87 \%$ of the variance of the total score on the scale. Each component was composed of one, two or three aggregate items. Internal consistency by Cronbach's a coefficient was 0.30. Conclusion: The factor analysis of the structure of the Minnesota Leisure Time Activities Questionnaire - Brazilian Portuguese- has shown a new range with 10 components, which explained, in total, more than $60 \%$ of the variance of the total score on the scale, yet with low internal consistency. Level of Evidence III; Study of nonconsecutive patients; without consistently applied reference "gold" standard.
\end{abstract}

Keywords: Aged; Physical activity; Questionnaire.

\section{RESUMO}

Introdução: Medidas acuradas de atividade física para estabelecer relação dose-resposta em desfechos de saúde ainda são controversas. Escalas que estimam o gasto calórico são propostas visando categorizar o fenômeno de forma global. Objetivo: Realizar a análise fatorial da estrutura do Minnesota Leisure Time Activities Questionnaire - português-Brasil e propor uma nova versão adaptada aos idosos comunitários brasileiros. Métodos: Participaram idosas, residentes da comunidade, sem distinção de raça elou classe social e frequentadoras de projetos de extensão de duas escolas de ensino superior. Excluíram-se aquelas com alterações cognitivas, marcha dependente, dores musculoesqueléticas nas últimas duas semanas e doenças neurológicas. Todas responderam ao questionário com dados sócio-clínico-demográficos e ao Minnesota Leisure Time Activities Questionnaireversão português-Brasil. Foi identificado se cada atividade tinha sido realizada e o número médio de vezes nas últimas duas semanas, considerando tempo médio, em minutos, em cada ocasião. Cada atividade foi considerada como um item e o gasto energético foi calculado de acordo com as instruções dos autores. Utilizou-se a análise fatorial com rotação ortogonal Varimax excluindo os itens cuja variância era igual a zero. A correlação entre os itens foi realizada pela matriz de correlação de Pearson. A consistência interna entre os itens, antes e depois da análise fatorial foi realizada através do coeficiente a de Cronbach. Nivel de significância de 5\%. Resultados: Participaram 220 mulheres (70,8 $\pm 5,9$ anos). A análise fatorial resultou em 10 componentes que explicaram no total $61,87 \%$ da variância da pontuação total na escala. Cada componente era composto por um, dois ou três itens agregados. A consistência interna pelo coeficiente a de Cronbach foi de 0,30. Conclusão: A análise fatorial da estrutura do Minnesota Leisure Time Activities Questionnaire - português-Brasil apresentou uma nova escala com 10 componentes que explicou no total mais de 60\% da variância da pontuação total na escala, porém com uma baixa consistência interna. Nível de Evidência Nível III; Estudo de pacientes não consecutivos; sem padrão de referência "ouro" aplicado uniformemente.

Descritores: Idoso; Atividade física; Questionário. 


\section{RESUMEN}

Introducción: Las medidas precisas de actividad física para establecer relación dosis-respuesta en los resultados de salud aún son controvertidas. Las escalas que estiman el gasto calórico son propuestas buscando categorizar el fenómeno de forma global. Objetivo: Realizar el análisis factorial de la estructura del Minnesota Leisure Time Activities Questionnaire-Portugués-Brasily proponer una nueva versión adaptada a los individuos de tercera edad comunitarios brasileños. Métodos: Participaron mujeres de tercera edad, residentes en comunidad, sin distinción de raza y/o clase social y frecuentadoras de proyectos de extensión de dos escuelas de enseñanza superior. Se excluyeron aquellas con alteraciones cognitivas, marcha dependiente, dolores musculoesqueléticos en las últimas dos semanas y enfermedades neurológicas. Todas respondieron el cuestionario con datos socio-clínico-demográficos y el Minnesota Leisure Time Activities Questionnaire - versión en portugués de Brasil. Se identificó si cada actividad había sido realizada y el número promedio de veces en las últimas dos semanas, considerando tiempo promedio, en minutos, en cada ocasión. Cada actividad fue considerada como un ítem y se calculó el gasto energético de acuerdo con las instrucciones de los autores. Se utilizó análisis factorial con rotación ortogonal Varimax excluyendo los ítems cuya varianza fue igual a cero. La correlación entre los elementos fue realizada por la matriz de correlación de Pearson. La consistencia interna entre los elementos, antes y después del análisis factorial fue realizada a través del coeficiente a de Cronbach. Nivel de significancia de 5\%. Resultados: Participaron 220 mujeres (70,8 55,9 años). El análisis factorial resultó en 10 componentes que explicaron en total 61,87\% de la varianza de puntuación total en la escala. Cada componente era compuesto por uno, dos o tres elementos agregados. La consistencia interna por el coeficiente a de Cronbach fue de 0,30. Conclusión: El análisis factorial de la estructura del Minnesota Leisure Time Activities Questionnaire - Portugués-Brasil presentó una nueva escala con 10 componentes que explicó en total más de $60 \%$ de la varianza de la puntuación total de la escala, aunque con una baja consistencia interna. Nivel de Evidencia Nivel III; Estudio de pacientes no consecutivos; sin estándar de referencia "oro" aplicado uniformemente.

Descriptores: Anciano; Actividad física; Cuestionario.

\section{INTRODUCTION}

The global population is aging rapidly. The forecast for 2020 is that Brazil will be the sixth country in the world in number of elderly people with more than 30 million individuals. ${ }^{1}$ This phenomenon will greatly increase the number of people who are dependent and have limitations, which reinforces the need to implement preventive health policies and measures. In this context, physical activity (PA) has been labeled one of the forms of prevention and control of chronic diseases for healthy aging. Yorston et al., ${ }^{2}$ in a population-based study, used a physical activity guide to identify frequency, intensity, duration, and type of activity performed. The authors demonstrated that those individuals engaged in moderate and intense PA had better functional conditions, suggesting that physical activity could be considered a predictor of function. ${ }^{2}$

However, the literature has indicated a drawback in using accurate measures of PA to establish the dose-response relationship in various health endpoints. ${ }^{3}$ In clinical practice and in research, there is a tendency, especially in epidemiological studies, to use questionnaires as a means of measuring and classifying activity and inactivity. However, PA is a multidimensional endpoint that must be characterized in terms of volume, domain, type, duration, intensity and frequency, which will often not be captured through a questionnaire. ${ }^{3}$ Thus, PA can be evaluated using both objective measures based on motion sensors, such as pedometers, accelerometers and Global Positioning Systems, ${ }^{4,5}$ and the doubly labeled water method, designated as gold standard. However, doubly labeled water has the disadvantage of being costly and not providing information on the intensity and frequency of the activity performed. ${ }^{6,7}$ Accordingly, despite being aware of the limitations of the questionnaires, and contemplating measures that can be applied in populations, it has been proposed that we use scales that estimate caloric expenditure, even though these are based on subjective information that may often not be categorizing and classifying the phenomenon as a whole. ${ }^{3}$
In this perspective, the Minnesota Leisure Time Activities Questionnaire is an instrument that was created by Taylor et al. (1978) to assess the level of physical activity, sports, and leisure according to energy expenditure. ${ }^{8}$ This instrument has been used in research on physical activity in various areas of health, particularly studies with cardiovascular endpoints. ${ }^{6,79,10}$ In our particular field it was recently translated into and adapted for Brazilian Portuguese, ${ }^{11}$ and is an instrument that has been used to evaluate caloric expenditure in the elderly, despite not having been adapted for this segment of the population.,10,12 Moreover, as the questionnaire includes several questions about activities that are not commonly undertaken by the Brazilian population, ${ }^{11}$ it would seem that an analysis of its structure is warranted to ensure adaptation to this population.

Hence, the aim of this study was to conduct a factor analysis of the Minnesota Leisure Time Activities Questionnaire - Brazilian Portuguese version (MLTAQ-Br), to propose a short version of this instrument, capable of capturing the level of physical activity of Brazilian communities of elderly individuals.

\section{MATERIAL AND METHODS}

This is a cross-sectional, observational, methodological study that used a convenience sample of elderly women. To this end, women aged 60 years and over classed as community residents and who frequented activity groups and extension projects of two higher education institutions were invited to participate, without any distinction regarding race and/or social class. The exclusion criteria were cognitive alterations detectable by the Mini-Mental State Examination, according to level of education, ${ }^{13}$ dependence on walking aids, complaint of musculoskeletal pain in the last two weeks and sequelae of neurological diseases. All participants signed the informed consent form.

The elderly women completed an interview-based questionnaire with socio-demographic and clinical data (health-related habits, medications used, presence of self-reported comorbidities, occurrence of 
falls, visual and auditory deficits and self-perception of health). After this they completed the Minnesota Leisure Time Activities Questionnaire (version translated into Brazilian Portuguese - MLTAQ-Br). ${ }^{11}$ The participants identified whether they had engaged in each activity within the last two weeks. If the reply was affirmative, they stated the average number of times, considering the average time, in minutes, spent on each occasion. Each activity was considered a single item and the energy expenditure in kilocalories (kcal) was calculated according to the authors' instructions. ${ }^{8}$ This study was approved by the Institutional Review Board of the Universidade Federal de Minas Gerais under the opinion with CAAE (Certificado de Apresentação para Apreciação Ética) [Ethics Evaluation Submission Certificate] number 0535.0.203.000-11.

The original version of the Minnesota Leisure Time Activities Questionnaire consists of 63 items. Activities are grouped into nine categories: walking, conditioning exercises, water activities, winter activities, sports, golf, gardening or cultivation of vegetables, household repairs, hunting, fishing, and other activities. ${ }^{8,14}$ The equation proposed by the authors: $I A M=\Sigma(I \times M \times F \times T)$, where $I A M=$ annual energy expenditure; $I$ = intensity of each activity in METs; $M=$ number of months/year in which the activity was performed; $F=$ average number of times it was performed in the month; $T$ = average duration of activity on each occasion, was used to reduce the data of the questionnaire and to interpret energy expenditure. To obtain the value in kilocalories (kcal), I was multiplied by the constant 0.0175 and the individual's weight in kilograms $(\mathrm{kg})^{8}$. This questionnaire is easy to administer, has a low cost, ${ }^{15}$ and its test-retest correlation coefficient was verified in a population-based study consisting of men and women aged between 25 and 74 years $(r=0.79-0.88, p<0.001) .{ }^{16}$

\section{Statistical analysis}

The descriptive characteristics of the sample were evaluated by the mean, standard deviation, or frequency distribution of the items in the sample.

The MLTAQ-Br was analyzed through the scores of the scale items using factor analysis. Thus, scale items with variance equal to zero, that is, activities that were not performed by any elderly woman in the sample, were excluded.

In this way, the analysis was conducted with 21 items that had non-zero variability among the 65 items of the original scale. To reduce the scale we conducted the factor analysis with Varimax orthogonal rotation, aiming at the aggregation of items based on their highest correlation. Prior to the factor analysis, a Pearson correlation matrix was applied to assess the correlation of the items. The factor analysis was based on the idea that a construct is formed by one or more dimensions that can be grouped on a basis of their higher correlations, thereby forming factors. Each factor represents the items that are most closely related to each other.

Internal consistency between the scale items, before and after the factor analysis, was verified using Cronbach's a (alpha) coefficient.

The analyses were carried out using the SPSS 17.0 statistical package. The significance level considered was $a=0.05$.

\section{RESULTS}

The participants were 220 women with a mean age of 70.8 (5.9) years. Other socio-demographic and clinical characteristics are shown in Table 1.

The factor analysis resulted in 10 factors, which explained, in total, $61.87 \%$ of the variance of the total score on the scale, which represents the total caloric expenditure reported by the elderly women. Those factors with eigenvalues greater than 1 were included. Each factor was composed of one, two, or three aggregate items. Although the items that made up each factor were apparently unrelated in terms of the activity they represented, they were strongly related in terms of the number of METs expended in each activity, which assumed similar values. The items that composed the factors are presented in Table 2. Although factors 8,9 and 10 contain only one item each, they were maintained because together they explained $15.55 \%$ of the total variance of results, and their withdrawal would impair the ability to explain the variation of scores on the scale and to identify differences in caloric expenditure among the elderly women in the sample.

Internal consistency was Cronbach's $a=0.30$. We also calculated the internal consistency of each factor separately, and the alpha of the scale with the 21 initial items. Although some factors had lower a values, it was decided to keep them in the scale in order to preserve the percentage of explanation of the variation of the score in the sample. In addition, Cronbach's analysis showed that the withdrawal of items would not significantly increase the alpha value of the scale, i.e., alpha after the reduction of items was higher than that previously recorded $(a=0.20)$. These data are presented in Table 3.

The final scale, according to the factors, is shown in Table 4.

Table 1. Sociodemographic and clinical characteristics of participants $(n=220)$.

\begin{tabular}{c|c}
\hline Characteristics & \\
\hline Age (years), mean (SD) & $70.8(5.9)$ \\
\hline BMI (kg/m²), mean (SD) & $28.7(5.1)$ \\
\hline MMSE, mean (SD) & $23.5(4.3)$ \\
\hline Rated their health as good/ very good, number (\%) & $123(55.9)$ \\
\hline Rated their health as fair/ poor, number (\%) & $97(44.1)$ \\
\hline Married, number (\%) & $98(44.5)$ \\
\hline Widowed, number (\%) & $108(49.1)$ \\
\hline Other marital status, number (\%) & $14(6.4)$ \\
\hline Illiterate, number (\%) & $52(23.6)$ \\
\hline Up to 7 years of school education, number (\%) & $135(61.4)$ \\
\hline More than 8 years of school education, number (\%) & $33(15)$ \\
\hline SD = standard deviation; BMI = Body Mass Index; MMSE=Mini-Mental State Examination.
\end{tabular}

Table 2. Items of the factors of the 18-item version of the Minnesota Leisure Time Activities Questionnaire and MET corresponding to each activity.

\begin{tabular}{|c|c|c|}
\hline Item* & Corresponding activity & MET \\
\hline $\mathrm{A} 010$ & Walking for pleasure & 3.5 \\
\hline A030 & $\begin{array}{l}\text { Voluntary use of stairs when the elevator or escalator } \\
\text { is available }\end{array}$ & 8.0 \\
\hline A040 & Ecological walking & 6.0 \\
\hline A050 & Walking with backpack & 7.0 \\
\hline A125 & Dancing & 5.5 \\
\hline B150 & Exercise at home & 4.5 \\
\hline B160 & Exercise in a club/fitness center & 6.0 \\
\hline B180 & Jogging - walking & 6.0 \\
\hline B210 & Muscle strengthening exercises & 6.0 \\
\hline $\mathrm{C} 280$ & Swimming in a pool & 6.0 \\
\hline E400 & Volleyball & 4.0 \\
\hline F560 & $\begin{array}{l}\text { Mowing the grass walking behind a motorized } \\
\text { lawnmower }\end{array}$ & 4.5 \\
\hline F580 & Weeding and cultivating garden/ vegetable garden & 4.5 \\
\hline F590 & $\begin{array}{l}\text { Loosening soil, digging, cultivating garden/vegetable } \\
\text { garden prior to planting }\end{array}$ & 5.0 \\
\hline F600 & Raking lawn & 4.0 \\
\hline F610 & Removing earth with a spade & 6.0 \\
\hline G630 & Interior painting or wallpapering of home & 4.5 \\
\hline 0000 & Moderate housework & 4.0 \\
\hline
\end{tabular}

MET = metabolic equivalent, Item* - nomenclature corresponding to the item of the original Minnesota Leisure Time Activities Questionnaire. 
Table 3. Minnesota Leisure Time Activity Questionnaire with 18 items - Factor Analysis Result, with factor loading, percentage of variance explained and Cronbach's a coefficient.

\begin{tabular}{c|c|c|c|c|c|c|c|c|c|c|}
\hline Item & \multicolumn{10}{|c|}{ Factor } \\
\hline & $\mathbf{1}$ & $\mathbf{2}$ & $\mathbf{3}$ & $\mathbf{4}$ & $\mathbf{5}$ & $\mathbf{6}$ & $\mathbf{7}$ & $\mathbf{8}$ & $\mathbf{9}$ & $\mathbf{1 0}$ \\
\hline A010 & 00.17 & -0.12 & -0.02 & 0.60 & 0.23 & 0.06 & -0.13 & 0.07 & 0.29 & 0.05 \\
\hline A030 & 0.88 & 0.19 & 0.03 & 0.01 & -0.02 & -0.01 & -0.03 & 0.01 & 0.03 & 0.01 \\
\hline A050 & 0.08 & 0.01 & -0.04 & -0.08 & 0.07 & 0.01 & $0 .-01$ & 0.88 & -0.03 & 0.01 \\
\hline A125 & -0.08 & 0.18 & $0 .-02$ & -0.04 & 0.70 & 0.11 & 0.25 & -0.06 & -0.12 & -0.10 \\
\hline A040 & -0.03 & 0.02 & -0.01 & -0.03 & -0.01 & 0.01 & 0.02 & $0 .-02$ & 0.05 & 0.96 \\
\hline B150 & 0.04 & 0.47 & 0.73 & 0.11 & 0.20 & -0.02 & -0.05 & 0.01 & -0.02 & -0.03 \\
\hline B160 & -0.07 & -0.04 & -0.03 & 0.75 & -0.06 & -0.05 & 0.07 & -0.19 & -0.17 & -0.01 \\
\hline B180 & -0.02 & -0.02 & 0.02 & -0.06 & -0.09 & 00.76 & -0.03 & 0.02 & -0.01 & 0.01 \\
\hline B210 & 0.01 & -0.01 & -0.02 & 0.05 & 0.10 & 0.78 & 0.01 & -0.03 & 0.01 & -0.03 \\
\hline C280 & 0.86 & -0.09 & -0.01 & -0.04 & -0.02 & -0.01 & 0.03 & 0.04 & -0.06 & -0.04 \\
\hline E400 & -0.01 & -0.12 & 0.92 & -0.08 & -0.06 & 0.01 & 0.02 & -0.03 & -00.98 & 0.01 \\
\hline F560 & 0.16 & 0.76 & 0.02 & 0.04 & -0.09 & 0.01 & -0.07 & -0.08 & 0.09 & 0.09 \\
\hline F580 & -0.15 & 0.12 & 0.08 & 0.52 & -0.17 & -0.03 & 0.07 & 0.43 & -0.04 & -0.13 \\
\hline F590 & -0.08 & 0.79 & 0.04 & -0.13 & 0.12 & -0.02 & 0.06 & 0.11 & -0.08 & -0.08 \\
\hline F600 & -0.04 & 0.02 & -0.01 & -0.04 & -0.04 & -0.01 & 0.05 & -0.04 & 0.92 & -0.05 \\
\hline F610 & 0.03 & 0.03 & -0.01 & -0.07 & 0.04 & 0.01 & 0.85 & -0.10 & -0.05 & -0.07 \\
\hline G630 & 0.02 & -0.09 & 0.06 & 0.04 & 0.79 & -0.07 & -0.14 & 0.08 & 0.06 & 0.06 \\
\hline SWEEP & -0.06 & -0.11 & 0.01 & 0.22 & -0.02 & -0.06 & 0.59 & 0.33 & 0.24 & 0.22 \\
\hline \% variance & 7.91 & 7.57 & 6.71 & 6.32 & 6.21 & 5.86 & 7.76 & 5.52 & 5.04 & 4.99 \\
\hline Cronbach a & 0.72 & 0.49 & 0.62 & 0.30 & 0.35 & 0.35 & 0.31 & -- & -- & -- \\
\hline Total variance with 10 components: 61.87\% & & & & & \\
\hline Total Cronbach's a: 0.30 & & & & & & & \\
\hline
\end{tabular}

Table 4. Final version of the Minnesota Leisure Time Activity with 18 items, separated by factors.

\begin{tabular}{c|c|c|c}
\hline Factor & Item & Activity & MET \\
\hline 1 & A030 & Voluntary use of stairs & 8.0 \\
\hline & C280 & Swimming in pool & 6.0 \\
\hline 2 & F560 & Mowing grass behind lawnmower & 4.5 \\
\hline & F590 & Loosening soil, digging, cultivating & 5.0 \\
\hline 3 & B150 & Exercise at home & 4.5 \\
\hline & E400 & Volleyball & 4.0 \\
\hline 4 & A010 & Walking for pleasure & 3.5 \\
\hline & B160 & Exercise at a club/fitness center & 6.0 \\
\hline & F580 & Weeding and cultivating & 4.5 \\
\hline 5 & A125 & Dancing & 5.5 \\
\hline 6 & G630 & Interior painting of home & 4.5 \\
\hline & B180 & Jogging - walking & 6.0 \\
\hline 7 & B210 & Muscle strengthening exercises & 6.0 \\
\hline & F610 & Removing earth with a spade & 6.0 \\
\hline 8 & 0000 & Moderate housework & 4.0 \\
\hline 9 & A050 & Walking with backpack & 7.0 \\
\hline 10 & A040 & Raking lawn & 4.0 \\
\hline
\end{tabular}

\section{DISCUSSION}

The aim of this study was to conduct a factor analysis of the structure of the Minnesota Leisure Time Activities Questionnaire - Brazilian Portuguese version in order to propose a new shorter version adapted for elderly members of the Brazilian population. The result showed a new scale with 10 factors that explained, in total, more than $60 \%$ of the variance of the total score on the scale, but with low internal consistency.

In recent years, PA has been the subject of several studies and the results have demonstrated the impact of a sedentary lifestyle on a number of health conditions, including aging and mortality. ${ }^{17}$ In this context, the estimation of a sedentary lifestyle has been evaluated mainly through questions about the duration, frequency and intensity of PA, which does not always reflect the true condition of the individual, due to the difficulty related to information. Similarly, lack of standardization in terms of the questions makes it difficult to interpret and compare data. On the other hand, the need for information on caloric expenditure, level of physical activity, sedentary lifestyle, etc. has increased our knowledge of aging and made it possible to predict and propose appropriate health measures for different populations. ${ }^{14}$ In this case, the result of this study, proposing a short (10-factor) scale that is easy to apply, standardized, and involves a variety of physical activities performed by the elderly, can help us to collect this information.

Although Heesch et al ${ }^{18}$ referred to questionnaires as being the most appropriate for epidemiological studies, following an analysis of the concurrent validity of a PA questionnaire, they argued that the use of MET was developed for people between 18 and 64 years old, and thus might not be the most suitable option for older individuals. ${ }^{18}$ On the other hand, Haskell et al ${ }^{19}$ proposed an update of PA recommendations for adults and indicated leisure activities of moderate and vigorous intensity, based on the MET value. According to these authors, leisure activities would correspond to less than $3 \mathrm{MET}$; moderate intensity, between 3 and 6 MET; and vigorous activities would be those above 6 MET. ${ }^{19}$ After the factor analysis of MLTAQ-Br conducted in this study, we observed 10 factors that correspond to the activities of moderate and vigorous intensity. In this context, it can be noted that the aggregation of activities clearly characterized the range of values indicated by the authors, i.e., between 3 and 6 MET and above 6 MET. Thus, the fact that there are no activities characterized as "leisure" activities - below 3 MET, may have been a limitation of the instrument. However, since there are not yet any specific PA questionnaires for the elderly, the proposition of this instrument may be the beginning of a series of investigations, comparing it with other more accurate instruments such as the pedometer, accelerometer, doubly labeled water, and others. Likewise, when Haskell et al ${ }^{19}$ mentioned the importance of assessing PA through weekly caloric expenditure, they indirectly stressed the need for standardized instruments using MET to make the calculation possible. ${ }^{19}$ In this case, the questionnaire proposed here may satisfy this need considering the elderly population.

After a literature review, the first investigation of PA in Brazil appeared through the 1996-97 Survey of Life Patterns, which studied 11,033 people over 20 years of age. ${ }^{17}$ The authors demonstrated low adherence to PA in all the age strata analyzed, having investigated only the performance of activities such as soccer, volleyball, walking, gymnastics, and others, through closed-ended questions. ${ }^{17}$ Besides not having conducted a comprehensive analysis of other physical activities, the caloric expenditure of the participants was not evaluated either, and the questions were not standardized. This fact reinforces the proposal of the MLTAQ-Br, evaluated in this study, and its 10-factor version, since it is believed that this instrument will allow an evaluation of PA that will reflect the lifestyle of elderly Brazilians, mainly in relation to moderate and vigorous activities.

It is also known that a good questionnaire must be homogeneous, that is, its items must evaluate different aspects of the same construct. ${ }^{20}$ In this case, the internal consistency analysis reflects the degree to which the different items of the questionnaire are associated. This measure is necessary to guarantee the homogeneity of the scale. ${ }^{21}$ Thus, a very low alpha demonstrates that some items may be evaluating another construct, whereas a very high alpha may demonstrate that some items could be redundant. ${ }^{20}$ In the case of the questionnaire analyzed in this study, the internal consistency found was not ideal, suggesting that there is no homogeneity among items. This result can be explained by the fact that the scale is measuring activities that vary in intensity, as discussed previously. Since it is a questionnaire to assess PA, and 
this is defined by the ACSM as'any bodily movement produced by the contraction of skeletal muscle that increases energy expenditure,22 it is believed to be important to include varied activities that may indicate differentiated intensities.

In this context, Tornos et $\mathrm{al}^{10}$ used the Minnesota Leisure Time Activities Questionnaire to assess leisure time activity, the frequency and intensity of these activities according to age, gender, body mass index and socioeconomic characteristics in the population studied. ${ }^{10}$ With the results found, the authors addressed the quality of the questionnaire, pointing out that this instrument uses day-to-day activities in places frequented daily, in addition to considering the commute to work. ${ }^{10}$ According to the authors, this advantage makes it possible to perform a comprehensive evaluation of an individual's energy expenditure. Thus, the new version proposed here includes activities that are customary for this segment of the population in its daily routine.

On the other hand, the same group of authors criticized the absence of a cut-off point to establish who is active, moderately active or inactive. ${ }^{10}$ In this case, it is believed that the cut-off point is not the most relevant aspect, since the objective of this questionnaire is not to classify individuals as to whether they are active or not. The most important aspect would be to identify the caloric expenditure during the week and thus facilitate evaluation, comparison and follow-up in various clinical situations and in research. Thus, the use of this questionnaire MLTAQ-Br - adapted to activities in Brazil, could be a good alternative for assessing the PA level of our elderly population, within the reality of their daily lives. In addition, some limitations should be pointed out with regards to this study. It is known that socioeconomic level often determines a lifestyle and consequently the physical activities adopted by the individual. As this study was not concerned with the economic stratum of this population, this may have influenced the answers.

\section{CONCLUSION}

The factor analysis of the structure of the Minnesota Leisure Time Activities Questionnaire - Brazilian Portuguese version (MLTAQ-Br) demonstrated a new scale with 10 factors, which explained, in total, more than sixty percent of the variance of the total score on the scale, but with low internal consistency. This new scale, proposed for elderly individuals, makes it possible to identify activities of moderate and vigorous intensity, based on the calculation of caloric expenditure.

\section{ACKNOWLEDGMENTS}

We thank the Pró-Reitoria de Pesquisa da Universidade Federal de Minas Gerais, Belo Horizonte, MG, Brazil, Conselho Nacional de Desenvolvimento Científico e Tecnológico (National Council for Technological and Scientific Development - (NPq), and the Coordenação de Aperfeiçoamento de Pessoal de Nível Superior (Coordination of Improvement of Higher Education Personnel - CAPES) for their support of our work.

All authors declare no potential conflict of interest related to this article.

AUTHORS' CONTRIBUTIONS: Each author made significant individual contributions to this manuscript. LPL (0000-0002-0919-1320)*:, SLAS (0000-0002-2323-2029)*: and RCD (0000-0002-1027-7746)*: were responsible for the conception, writing, statistical analysis, discussion of results, revision and final approval of the manuscript; LPL and TAM (0000-0003-1128-0979)*: participated in the data collection and discussion of results; LSMP (0000-0001-7253-4392)* and JMDD (0000-0002-5660-4108)*: participated in the discussion of results, writing and critical review of the intellectual content. All authors contributed to the intellectual concept of the study and approved the final version of the manuscript. ${ }^{*} \mathrm{ORCID}$ (Open Researcher and Contributor ID).

\section{REFERENCES}

1. Veras R. Envelhecimento populacional contemporâneo: demandas, desafios e inovações. Rev Saúde Pub. 2009:43(3):548-54.

2. Yorston LC, Kolt GS, Rosenkranz RR. Physical activity and physical function in older adults: the 45 and up study. J Am Geriatr Soc. 2012;60(4):719-25

3. Borch KB, Ekelund U, Brage S, Lund E. Criterion validity of a 10-category scale for ranking physical activity in Norwegian women. Int J Behav Nutr Phys Act. 2012;9:2-8.

4. Gill DP, Jones GR, Zou G, Speechley M. Using a single question to assess physical activity in older adults: a reliability and validity study. BMC Medical Research Methodology. 2012;28:12-20.

5. Neilson HK, Robson PJ, Friedenreich CM, Csizmadi I. Estimating activity energy expenditure: how valid are physical activity questionnaires? Am J Clin Nutr. 2008;87(2):279-91.

6. Starling RD, Toth MJ, Carpenter WH, Matthews DE, Poehlman ET. Energy requirements and physical activity in free-living older women and men: a doubly labeled water study. J Appl Physiol. 1998;85(3):1063-9.

7. Starling RD, Matthews DE, Ades PA, Poehlman ET. Assessment of physical activity in older individuals: a doubly labeled water study. J. Appl. Physiol. 1999;86(6):2090-6.

8. Taylor HL, Jacobs Jr DR, Schucker B, Knudsen J, Leon AS, Debacker G. A questionnaire for the assessment of leisure time physical activities. J Chronic Dis. 1978;31(12):741-55.

9. Mahabir S, Baer DJ, Giffen C, Clevidence BA, Campbell WS, Taylor PR, et al. Comparison of energy expenditure estimates from 4 physical activity questionnaires with doubly labeled water estimates in postmenopausal women. Am J Clin Nutr. 2006;84(1):230-6.

10. Tornos IS, Iribas CM, Rueda JJ, Uche AM, Goñi CA, Martínez MS. Estudio poblacional de actividad física en tiempo libre. Gac Sanit. 2009;23(2):127-32

11. Lustosa LP, Pereira DS, Dias RC, Britto RR, Parentoni AN, Pereira LS. Tradução e adaptação transcultural do Minnesota Leisure Time Activities Questionnaire em idosos. Geriatria \& Gerontologia. 2011;5(2):57-65.
12. Mouton CP, Calmbach WL, Dhanda R, Espino DV, Hazuda H. Barriers and benefits to leisure-time physical activity among older Mexican Americans. Arch Fam Med. 2000;9(9):892-7.

13. Bertollucci PH, Brucki SM, Campacci SR, Juliano Y. O Mini-exame do estado mental em uma população geral: impacto da escolaridade. Arq Neuropsiquiatr. 1994;52(1):1-7.

14. Conway JM, Irwin ML, Ainsworth BE. Estimating energy expenditure from the Minnesota Leisure Time Physical Activity and Tecumseh Occupational Activity questionnaires: a doubly labeled water validation J Clinical Epidemiol. 2002;55(4):392-9.

15. Kramer AF, Erickson KI, Colcombe SJ. Exercise, cognition and the aging brain. J Appl Physiol. 2006;101(4):1237-42.

16. Folsom AR, Jacobs Jr DR, Caspersen OG, Knudsen J. Test-Retest reliability of the Minnesota Leisure Time Physical Activity Questionnaire. J Chronic Dis. 1986;39(7):505-11.

17. Monteiro CA, Conde WL, Matsudo SM, Matsudo VR, Bonseñor IM, Lotufo PA. A descriptive epidemiology of leisure-time physical activity in Brazil, 1996-1997. Rev Panam Salud Publica. 2003;14(4):246-54.

18. Heesch KC, Hill RL, van Uffelen JG, Brown WJ. Are active Australia physical activity questions valid for older adults? J Sci Med Sport. 2011;14:233-7.

19. Haskell WL, Lee IM, Pate RR, Powell KE, Blair SN, Franklin BA, et al. Physical Activity and Public Health updated recommendations for adults from the American College of Sports Medicine and the American Heart Association. Circulation. 2007;116:1081-93.

20. Maher CG, Latimer J, Costa LO. The relevance of cross-cultural adaptation and clinimetrics for physica therapy instruments. Rev Bras Fisioter. 2007;11(4):245-52.

21. Portney LG, Watkins MP. Foundations of Clinical Research: application to practice. 3th. ed. Pearson/ Prentice Hall. 2009. 892p.

22. Chodzko-Zajko WJ, Proctor DN, Fiatarone Singh MA, Minson CT, Nigg CR, Salem GJ, et al. Exercise and physical activity for older adult. Med Sci Sports Exerc. 2009;41(7):1510-30. 